\title{
Awakening through Career Woman: Social Capital for Javanese Migrant Worker on Southeast Asia
}

\author{
Anggaunitakiranantika \\ Sociology Department, Social Science Faculty \\ State University of Malang, East Java-Indonesia \\ anggaunita@gmail.com
}

\begin{abstract}
Becoming a career woman is a wish for most Javanese woman when living from agricultural system is not good for their survival mechanism nowadays. Not only high quality of standard living but also lifestyle has influence most Javanese women changing their mindset and becoming career woman is the solution through this problem. Career importance for Javanese meant woman have met with public sector occupation, include become migrant worker as happening for last decade in Indonesia. This article figures out the Javanese woman who constructing their career as a migrant worker on Southeast Asia country, such as Malaysia, Singapore and Brunei Darussalam succeed reach the goal as a career woman. Based on qualitative research, Javanese migrant worker who stayed at Southeast Asia country creating career system with strengthening collective consciousness and contracting Javanese identity on each country by family hood. In line with this situation, social capital evolving as a key through career for Javanese migrant worker and renowned as recruitment mechanism among them. Thus, within a decade, tracer into succeed Javanese migrant worker influence another Javanese in Indonesia by following same path, having communication until they have got a career on Southeast country and line up their family hood, having leisure time as migrant worker career woman by hang out or having lunch together and constructing the new identity as New International Javanese with modern lifestyle, being autonomous, and commercial.
\end{abstract}

Keyword: career, javanese woman, social capital, migrant worker, southeast asia

\section{INTRODUCTION}

After the global crisis on Indonesia, reported national economy is getting better. Recognized or not, as a result of sluggish real sector happens next percentage of poor people remains high while no less alarming the increasing number of unemployment in East Java. According to several sources of employment, East Java Province has been addition of new workforce average of about 600 thousand per year, and of that number only about $20-30 \%$ absorbed in the formal economy. More about 70-80 \% are forced to work in the informal economy.

Becoming a career woman is a wish for most Javanese woman when living from agricultural system is not good for their survival mechanism nowadays. Not only high quality of standard living but also lifestyle has influence most Javanese women changing their mindset and becoming career woman is the solution through this problem. Career importance for Javanese meant woman have met with public sector occupation, include become migrant worker as happening for last decade in Indonesia.

This phenomenon spreading in many areas on East Java Province while transition on manufacturing sector becomes the leading one. Javanese woman on East Java Province getting more enthusiasm reaching career because they have been realized into the gender equality in that case woman got their right on pursuing dreams and hopes, another reason is decision making through career woman decided by couples too. Furthermore, struggling is needed the high-cost of everything when mother in a family got job, they are already strongly funding family. Data from Indonesian National Agency for the Placement and Protection of Overseas Labor (BNP2TKI) shows during January to December 2014 and released on January 2015, amount 429.872 Indonesian worker consisting 243.629 (57\%) women migrant worker and 186.243 (43\%) men migrant worker. Divided into origin of women migrant worker, there are West java as the prominent of transnational migrant worker in sequence with Central Java, East Java, Nusa Tenggara Barat and South Sumatera. Latest data from BNP2TKI released that Indonesian worker preferring some popular destination as Malaysia, Taiwan, Saudi Arabia, Hong Kong and Singapore for their economic survival system.

Reflecting from data, condition of transnational Indonesian worker is dynamics and fluctuating on 3 years. Begin with 494.609 worker on year 2012, increasing on 2013 into 512.168 and got decreased until 429.872 on 2014. Hence, it caused by moratorium on some middle-east countries for Indonesian worker such as Kuwait, Jordanian, Suriah, Saudi Arabia, Qatar and UEA. Available data on the number of Indonesian migrant working overseas, including data on Indonesian domestic workers going to Singapore show a steady upward trend in migration in the aftermath of the crises of the 1990s (Sim, in this volume). The economic imperative has been paramount in most migration decisions, particularly in the aftermath of the 1998 financial crisis. According to the Indonesian National Agency for the Placement and Protection of Overseas Labor (BNP2TKI), official remittances from Indonesian overseas migrants reached US\$7.98 billion in 2014. While fully acknowledging the importance of economic factors, this article goes beyond a purely economic framework in 
its discussion of the circulation and encounters of Indonesian female migrants.

\section{JAVANESE MIGRANT WORKER CAREER SYSTEM}

The Indonesian state discourse on a woman's role, linked to a particular notion of femininity termed Ibu-ism [1], has created an imaginary boundary of space for Indonesian Women The discourse situates women's place in the kinship system centering on their role as mothers, which firmly grounds them in the home. This way of thinking has also tended to restrict the range of 'feminine jobs' available to women, despite their increased access to education as well as vocational and professional training. Two major forces in women's lives, viz. the discourse of the state ideology of womanhood, Ibu-ism and a discourse of traditional cultural values, are encapsulated in familial and kin-based institutions in Indonesia [1], and mutually reinforce each other as determinants of 'propriety' for a woman. Propriety for a woman is then interpreted as respecting and remaining within defined boundaries or limits for gender behavior, including in respect of spatial mobility. Domestic tasks at home, such as taking care of children, cooking, fetching water and weaving tenun ikat or hand-woven textiles become, by dint of repetition, a natural part of women's daily lives.

Propriety for a woman is then interpreted as respecting and remaining within defined boundaries or limits for gender behavior, including in respect of spatial mobility. Domestic tasks at home, such as taking care of children, cooking, fetching water and weaving tenun ikat or handwoven textiles become, by dint of repetition, a natural part of women's daily lives. Women's mobility patterns and behavior are also constrained by the notion of 'propriety,' reinforced by fear of public disapproval of any transgression of the clearly defined gender boundaries.

In spite of increased women's mobility in terms of study and work in urban areas, migration further afield is quietly regulated and decided by people other than the women themselves. A male head of kin continues to have authority and to exercise control over women's mobility. Wolf's study on Ford said on daughters' decision making in Java suggests that the decision maker in the family- the one who makes important decisions on behalf of the rest of the family - occupies a powerful position in kin hierarchy. There are problematic relations of gender, in which achieving a high status for women may mean conforming to the female subjection implicated in the experiences of non-autonomous everyday lives [2]. Male kin are traditionally able to contain women's mobility. Such control over women's movement is designed to keep the reins on women's sexuality and this is commonly practiced in other places in Indonesia. Fathers protect and control a young woman's sexuality until she marries, at which time her husband becomes her guardian. Women's sexuality, their reputation and their marriage prospects are an extended family business.

\section{SOCIAL CAPITAL ON SOCIOLOGY OF MIGRATION}

The first systematic contemporary analysis of social capital was produced by Pierre Bourdieu, who defined the concept as. the aggregate of the actual or potential resources which are linked to possession of a durable network of more or less institutionalized relationships of mutual acquaintance or recognition [3]. This initial treatment of the concept appeared in some brief. Provisional Notes. published in the Actes de la Recherché en Sciences Sociales in 1980. Because they were in French, the article did not garner widespread attention in the English-speaking world; nor, for that matter, did the first English translation, concealed in the pages of a text on the sociology of education [3].

This lack of visibility is lamentable because Bourdieu's analysis is arguably the most theoretically refined among those that introduced the term in contemporary sociological discourse. His treatment of the concept is instrumental, focusing on the benefits accruing to individuals by virtue of participation in groups and on the deliberate construction of sociability for the purpose of creating this resource. In the original version, he went as far as asserting that. the profits which accrue from membership in a group are the basis of the solidarity which makes them possible. [3]. Social networks are not a natural given and must be constructed through investment strategies oriented to the institutionalization of group relations, usable as a reliable source of other benefits.

Bourdieu's definition makes clear that social capital is decomposable into two elements: first, the social relationship itself that allows individuals to claim access to resources possessed by their associates, and second, the amount and quality of those resources. emphasis is on the fungibles of different forms of capital and on the ultimate reduction of all forms to economic capital, defined as accumulated human labor. Hence, through social capital, actors can gain direct access to economic resources (subsidized loans, investment tips, protected markets); they can increase their cultural capital through contacts with experts or individuals of refinement (i.e. embodied cultural capital); or, alternatively, On the other hand, the acquisition of social capital requires deliberate investment of both economic and cultural resources. Though Bourdieu insists that the outcomes of possession of social or cultural capital are reducible to economic capital, the processes that bring about these alternative forms are not. They each possess their own dynamics, and, relative to economic exchange, they are characterized by less transparency and more uncertainty. For example, transactions involving social capital tend to be characterized by unspecified obligations, uncertain time horizons, and the possible violation of reciprocity expectations. But, by their very lack of clarity, these transactions can help disguise what otherwise would be plain market [3].

Coleman defined social capital by its function as. a variety of entities with two elements in common: They all consist of some aspect of social structures, and they facilitate certain action of actors. Whether persons or corporate actors. Within the structure. [4]. This rather 
vague definition opened the way for relabeling a number of different and even contradictory processes as social capital. Coleman himself started that proliferation by including under the term some of the mechanisms that generated social capital (such as reciprocity expectations and group enforcement of norms); the consequences of its possession (such as privileged access to information); and the appropriable social organization that provided the context for both sources and effects to materialize.

Resources obtained through social capital have, from the point of view of the recipient, the character of a gift. Thus, it is important to distinguish the resources themselves from the ability to obtain them by virtue of membership in different social structures, a distinction explicit in Bourdieu but obscured in Coleman. Equating social capital with the resources acquired through it can easily lead to tautological statements.

Bounded solidarity is the term used in the recent literature to refer to this mechanism. It is the source of social capital that leads wealthy members of a church to anonymously endow church schools and hospitals; members of a suppressed nationality to voluntarily join life-threatening military activities in its defense; and industrial proletarians to take part in protest marches or sympathy strikes in support of their fellows. Identification with one's own group, sect, or community can be a powerful motivational force. Coleman refers to extreme forms of this mechanism as. zeal. and defines them as an effective antidote to free-riding by others in collective movements [5]. The final source of social capital finds its classical roots in Durkheim's ([1893 -1984) theory of social integration and the sanctioning capacity of group rituals.

A review of the literature makes it possible to distinguish three basic functions of social capital, applicable in a variety of contexts: $(a)$ as a source of social control; $(b)$ as a source of family support; $(c)$ as a source of benefits through extra familial networks.

\section{RESEACH METHOD AND PROCESSES}

This article figures out the Javanese woman who constructing their career as a migrant worker on Southeast Asia country, such as Malaysia, Singapore and Brunei Darussalam succeed reach the goal as a career woman. Based on qualitative research, Research process was based primarily on non-random sampling but using snowball system. Observing least 30 Javanese Women followed by in-depth interview and were conducted either in Bahasa or Javanese. Javanese women comes from several rural areas in East Java Province, 8 women comes From Banyuwangi, 8 women comes from Tulungagung, 6 women comes from Blitar, 4 2omen comes from Malang, 3 Comes From Pacitan and 1 women comes from Probolinggo.

In general, most of the Javanese maid were in their $25 \mathrm{~s}$ and $30 \mathrm{~s}$, single rather than married and about half of them had completed education until junior high school. This research focus into Javanese women whoever going to Singapore, Malaysia and Brunei Darussalam for pursuing dreams.
During in-depth interview, they were asked about life experience, transnational migration that had been chosen to Singapore, Malaysia and Brunei Darussalam including reasons for seeking work there as a maid, their feeling about distinguished space about home and family on Indonesia, and also about their identity there for today. This study also drew on focus group discussions with small groups taken at Several areas on East Java, Indonesia. While a few Javanese migrants interviewed, I found difficulty when trying to get along with them although we have similarity based on origin place. "talking to strangers" warming up begin with assurances of confidentiality and discovering their views about identity and their everyday worlds only. Like others, I found interview transcript contained moment of poignancy, fear, anger, sadness and emptiness as the women recounted difficulties and indignities which they had undergone on transnational migration.

These narratives of Javanese women's life journey to Singapore, Malaysia and Brunei Darussalam should not be viewed as factual accounts as their identity but constructions which are selective in nature, culled from a combination of daily experiences and current evaluations of past events, about social capital and collective consciousness as an identity on temporary place of sojourn. In attempting relation and analyze these narratives, I am trying to breaking down the concept from question form into matrix that interweaving Javanese women's representation with my evaluations, steering carefully for a way forward without imposing preconceived categories which are reproducing details of every individual's perception of self.

\section{SOCIAL CAPITAL ON JAVANESE MIGRANT WORKER}

Migrant social networks are quite different from others in terms of their composition, how they are used, and the effect they have on the lives of millions of people currently living and working away from home. While the notion that social networks play a role in one's life may seem quite obvious, the importance of migrant networks in affecting outcomes for migrants, their families, and their communities cannot be overstated.

Understanding on Javanese migrant worker, social networks created within time, when they are come from another area in Java, Indonesia and having status as Javanese citizenship having the same job as domestic worker in Southeast Asia. These facts happened for certain time

Bourdieu's definition makes clear that social capital is decomposable into two elements: first, the social relationship itself that allows individuals to claim access to resources possessed by their associates, and second, the amount and quality of those resources. Throughout, Bourdieu's emphasis is on the fungible of different forms of capital and on the ultimate reduction of all forms to economic capital, defined as accumulated human labor. Hence, through social capital, actors can gain direct access to economic resources (subsidized loans, investment tips, 
protected markets); they can increase their cultural capital through contacts with experts or individuals of refinement (i.e. embodied cultural capital); or, alternatively, On the other hand, the acquisition of social capital requires deliberate investment of both economic and cultural resources

\section{COLLECTIVE CONSCIOUSNESS AS AN IDENTITY FOR JAVANESE MIGRANT WORKER}

Through looking into the collective actions of migrant workers in the Southeast country, this article sets out to make sense of the realities and complexities of the making of a new class. Collective consciousness is the attitudes, values, and beliefs of the group that define its outlook or how things are or are supposed to be. It is what can be called the group ethos, consensus, the world outlook of a group, common understanding, or weltanschauung that transcends individuals but binds the whole social group

We argue that most of the recent collective actions engendered Javanese workers' association with another at the several melting pot on Southeast country, such as Singapore, Malaysia and Brunei Darussalam while simultaneously entailing labor organizing and collective actions on the terrain of daily reproduction at the workers' dormitories and communities. The nature of these collective actions is mostly interest-based, accompanied by a capital surround and building community towards strengthening identity as Javanese women. These collective actions were organized not only on bases of locality, ethnicity, gender and peer alliance in a single workplace, but also attempted to nurture workers' solidarity in their way with doing happiness together with another Indonesian migrant worker on week end.

With rich insights from various studies of collective actions of Javanese women who gain as domestic workers in Southeast Asia we learn that "workers' identity", "class consciousness" and "labor struggles" are highly contested notions, requiring further sophisticated theorizing based on in-depth historical and sociologic studies. class happens when some women as a result of common experiences (inherited or shared), feel and articulate the identity of their interests as between themselves, and as against other men whose interests are different from (and opposed to) theirs. In the new industrial zones of Southeast Asia, where the language of class was subsumed and where collective actions are approving as differences between social class that happens in Singapore, Malaysia and Brunei Darussalam.

\section{CONCLUSION}

As one of the points of sojourn for many domestic workers in the Southeast Asian region, Singapore, Malaysia and Brunei Darussalam is seen by Javanese women as the land of opportunity and land of hope to achieve their goals before they return home. Yet Singapore, Malaysia, Brunei Darussalam itself, for this current generation of "unskilled" labor migrants, is not seen as the ultimate destination but a mere transit point, an endorsement of both the effectiveness of labor policies and its status as one of the points of convergence for the global lines of labor migrants characterizing global cities today.

Despite careful plans, the anticipated end of the journey for the Javanese women may be postponed, and even elusive or illusory in many ways, when new hopes and dreams emerge as the plans of the women themselves, their employers, or even their families change either for better or worse.

\section{REFERENCES}

[1] Ford, Michelle, Parker,Lyn, 2008. Women \& Work in Indonesia. London: Routledge.

[2] Huang, Shirlena, \& Yeoh, Brenda S.A. 1996. Ties that bind: State policy and migrant female domestic helpers in Singapore. Geoforum, 27 (4), 479-493.

[3] Bordieau, Peter. 1985. The Forms of Capital: handbook of Theory and Research for the Sociology of Education. New York: Greenwood.

[4] Coleman, James. 1988. Social Capital in the Creation of Human Capital. American Journal Sociology, 94, 95-121

[5] Portes, Alenjandro. 1998 Social Capital: Its Origins and Applications in Modern Sociology. Berkeley: University California Press 